\title{
Intensification of rice based cropping system incorporating short duration oilseed mustard varieties
}

\author{
L. Hassan*, M. A. Quddus, M. A. H. Khan ${ }^{1}$ and Mohammed Ali ${ }^{2}$ \\ Department of Genetics and Plant Breeding, 'Chief Farm Superintendent (Retired), Farm Management Section,, \\ Bangladesh Agricultural University, Mymensingh-2202, Bangladesh and ${ }^{2}$ Bittohin Chashi Somaj Kallayan Sangstha, \\ School Para, Airport Road, Ishwardi, Pabna, *E-mail: Iutfulhassan@yahoo.co.uk
}

\begin{abstract}
An attempt was taken to transform Aman-fallow-Boro cropping pattern into Aman-rapeseed and mustard-Boro for three years beginning from Rabi 2011-12. Two components viz. Bangladesh Agricultural University, Mymensingh (BAU) and Bittohin Chashi Somaj Kallayan Sangstha (BCSKS) executed the programme under the leadership of BAU. Three upazillas viz. Mymensingh Sadar, Muktagacha \& Haluaghat of Mymensingh district were under BAU component. Whereas, the upazillas Bagha of Rajshahi, Ishwardi of Pabna and Lalpur of Natore districts were under BCSKS component. A total of 1200 farmers $(300+400+500$ for 1 st, 2 nd \& 3rd years) were taken into consideration to grow rapeseed and mustard in between Aman \& Boro. Each of the farmers were provided with $1 \mathrm{~kg}$ rapeseed and mustard seeds, necessary fertilizers, insecticide, fungicide \& irrigation costs. Five rapeseed and mustard varieties namely BARI sarisha 14 \& 15, BINA sarisha 4 \& 7 and Unnata Tori 7 were used. Before rapeseed and mustard cultivation, all the farmers grew Aman rice \&Boro rice after harvesting it. Among the five rapeseed and mustard varieties BARI sarisha $14 \& 15$, BINA sarisha 4 and Unnata Tori 7 were found to be suitable for the cropping pattern Aman-rapeseed and mustard-Boro. These varieties matured between 76.9 to 84.1 days. Per hectare seed yield of the varieties ranged from $1266.5 \mathrm{~kg}$ (Unnata Tori 7) to $1822.0 \mathrm{~kg}$ (BARI sarisha 14) with an average of $1544.6 \mathrm{~kg}$. On an average per hectare cost of production, gross income \& gross return from rapeseed and mustard were tk. 27770, 78180 and 50471, respectively. On an average, over three years gross income and gross return obtained from Aman and Boro rice were tk. 52,273 \&22237 and tk. 71,138 \& 30,935 per hectare, respectively. Thus, an additional income of tk. 50471 obtained by the farmers for growing rapeseed and mustard in between Aman \& Boro over that of Aman \& Boro only, and cropping intensity of the farmers raised into $300 \%$.
\end{abstract}

Keywords: Crop intensification, Short duration, Mustard, Food security

\section{Introduction}

Agricultural intensification is an increase in the productivity of existing land and water resources in the production of food and cash crops, livestock, forestry, and aquaculture. Generally associated with increased use of external inputs, intensification is now defined as the more efficient use of production inputs. Increased productivity comes from the use of improved varieties and breeds, more efficient use of labor, and better farm management [1].

Intensification that depends essentially on greater use of external inputs is not the only kind of intensification available. There are other approaches to intensification to be considered under the rubric of agroecology [2-4].

In recent years, something called the system of crop intensification $(\mathrm{SCl})$ has emerged in a number of Asian and African countries, raising the productivity of the land, water, seed, labor, and capital resources that farmers invest can for growing a wide range of crops [5-7].

Bangladesh is an agriculture based country. It will remain so for long future. Here twelve months of a year has distinctly defined as three cropping seasons like Kharif-I, Kharif-II and Rabi. Boro/Aus and Aman rice are the major crops of Kharif-I and Kharif-II, respectively. Vegetables, oilseeds, pulses, spices etc. are largely grown in the rabi season. 
Bangladesh attained almost self-sufficiency in food -grains/cereal grains (rice, wheat, maize etc.) production. All these are sources of carbohydrates. If we consider potato with it, another major source of carbohydrate, then we are surely surplus in it. This unique achievement in a small country bearing more than 160 million people, where cultivable lands are reducing sharply every year are due to proper attention on research, seed production and dissemination of the above mentioned crops. But so far little attention has been paid on oilseeds, pulses, spices etc. and the country is facing huge shortage in all these crop areas.

At times Aus and Aman are the main rice growing seasons of the country when considerable fallow lands found to remain for growing rabi crops. Now-a-days especially rice are grown throughout the year and fallow land for growing a major crop whose life span is 100 or more days are very scarce. This is a general picture from crop production point of view. But from farmer's point of view, generally farming is not a profitable way of living at the present times. This has many reasons but most of the farmers had no other alternative rather than to continue this profession. On the other hand to feed the ever growing people from the continuously decreasing cultivable land there is no other way but to increase cropping intensity of the country. This will help the farmers to get increased production and financial status.

Bangladesh is facing huge shortage in edible oil production .About two-third of the country's need are imported every year by spending huge amount of foreign currency. On the other hand years together growing rice continuously in a piece of land charges soil texture, nutrient status of the soil, weed habitants of the land, soil-borne diseases and insects etc. So, it is essential to follow crop rotation or at least incorporation of a different crop between two rice crops. So, incorporation of rapeseed between aman and boro will increase oilseed production of the country, total income and nutritional status of the farmers. Simultaneously it will bring ecological balance in nutrient status of the soil, reduce soil-borne diseases and insects and increase eco-friendly weed etc.

The genus Brassica consists of a large number of cultivated species. The species comprises two major crop plant groups such as oilseed group and vegetable group. The cultivated oilseed species are $B$. nigra $(2 n=16)$, B. campestris $(2 n=20), B$. carinata $(2 n=34), B$. juncea $(2 n=36)$ and $B$. napus $(2 n=38)$. Among these, $B$. campestris and $B$. napus are commonly known as rapeseed; where as the other three species are known as mustard. In Bangladesh varieties B. campestris, both brown sarson and yellow sarson ecotypes are largely grown. In addition a few varieties of B. juncea which are generally late in maturity are grown in low lying areas and in late plantings.

\section{Materials and Methods}

An attempt was taken to transform Aman-Fallow-Boro cropping pattern into Aman-Rapeseed and mustard-Boro for increasing cropping intensity, oilseed production of the country as well as net income of the farmers by using short duration aman rice and also short duration rapeseed and mustard varieties. With the view point 1200 farmers were selected over three years June, 2011 to may 2014 from the upazillas of Mymensingh sadar, Muktagacha and Haluaghat of Mymensingh district (Bangladesh Agricultural University (BAU) Component) and Ishwardi, Bagha and Lalpur upazillas of Pabna, Rajshi and Natore districts (Bittohin Chashi Somaj kallayan Sangstha (BCSKS) component), respectively. During farmer selection priority was given to the interested ones who will follow the cropping pattern AmanRapeseed and mustard-Boro. The selected farmers were trained about general pattern of livelihood, calories and nutritional requirements of a person, sources of calories and nutrition, present cropping pattern and cropping intensity of the country, future programs to be taken, quality seed production, distribution and use etc. During training, three technology sheets covering Aman, rapeseed and mustard \& Boro were distributed. In addition of the farmers 37 extension service providers were trained and DAE/BADC/SCA personnel's were also present. Each of the selected farmers were provided with $1 \mathrm{~kg}$ rapeseed and mustard seeds, fertilizers, fund for insecticide \& fungicide. The rapeseed and mustard varieties used were BARI sarisha 14, 15; BINA sarisha 4, 7 and Unnata Tori 7 . For collecting data on various aspects a questionnaire/data collection sheet was prepared. Before going for data collection the data collectors/ Field assistants were also trained for appropriate and uniform data collection. 


\section{Results and Discussion}

A total of 1200 farmers were selected and studied for 3 years. Among them 300, 400 and 500 were at first, second and third year, respectively. Among the farmers, 50 percent were at BAU component and remained 50 percent at BCSKS component. A base line survey of the farmers were studied and found variable cropping pattern in the selective upazillas of which Aman-fallow-Boro cropping pattern covered about 41 percent of the total cropped areas. The farmers were distributed among the upazillas sometimes in equal numbers and sometimes in unequal numbers depending on available land, interested farmers, communication facilities etc. Among the 300 farmers of the 1st year study, a background assessment of the farmers such as age, educational qualification and occupation were studied. According to the study age of the farmers ranged from 18 to 80 years. Educational qualification ranged from illiterate to M.A. of which highest percentage (34\%) were between class VI to class VIII. In respect of occupation $83.34 \%$ farmers had farming occupation. Others were teacher, business, service, driver etc.

Before rapeseed and mustard cultivation all the farmers grew Aman rice. The farmers used more than ten varieties of which BINA dhan 7, an early variety of Amanrice, matures within 110 days grown by 47 percent farmers. Cost of production and gross income obtain from Aman rice has been calculated. On an average cost of production was tk. 30,036 per hectare and gross income was tk. 52,273 per hectare. Thus, gross return achieved from per hectare Aman rice was tk. 22,237.

During the three years study period, seeds of five rapeseed and mustard varieties were supplied to the farmers. All the varieties were not given in each year and in each of the upazillas. In the 1st year all the 300 farmers were supplied with the variety BARI sarisha-15. In addition, 15 farmers at BAU component were supplied the variety Unnata Tori-7. This variety, Unnata Tori-7 was not in the schedule because of the fact that though this a short duration variety but its seed yield and oil content are less than the high yielding ones. But after getting the results it was found that the farmers liked it very much. The farmers who transplanted Aman rice a bit late and or used a late variety; they preferred it, to grow Boro rice at the appropriate time. So, in the 2 nd and 3rd years study we supplied seeds of Unnata Tori-7 at a large scale.

Days to maturity is an important issue for the present study because we need early maturing rapeseed and mustard varieties and also early maturing Aman rice to fit into the cropping pattern, Aman-Rapeseed and mustard-Boro. Thus, we mostly used the early maturing Aman rice variety BINA dhan-7. In case of rapeseed and mustard varieties, Unnata Tori-7 was the earliest one (76.9 days) which was followed by BARI sarisha-14(79.2days), BARI sarisha-15 (84.1 days) and BINA sarisha- 4 (83.7days), All these four varieties may be considered as early maturing ones for the cropping pattern, Aman-Rapeseed and mustard-Boro.

In oil crops, the end product may be total seed yield or total oil production or both. Higher seed yield may contribute higher oil yield. On the other hand higher oil percentage in the seeds may also contribute higher oil yield. Generally, the yellow seeded varieties have higher oil content (42-44\%) than the brown seeded varieties (35-38\%). So, naturally market price of the yellow seeds are higher than the brown seeds and this was counted while estimating return obtained by the farmers from their products. However, seed yield of the five rapeseed and mustard varieties over three years have been shown in the Table 1. According to the table, on an average highest $1822 \mathrm{~kg}$ seeds/ha produced by the variety BARI sarisha-14. The $2^{\text {nd }}$ and $3^{\text {rd }}$ highest yields were 1651 and 1573 produced by the varieties BINA sarisha- 4 and BARI sarisha-15, respectively. All these are yellow seeded varieties. While the brown seeded variety Unnata Tori-7 produced $1266 \mathrm{~kg}$ seeds/ha. Considering all the varieties the average seed yield was 1544 $\mathrm{kg} / \mathrm{ha}$. 
Table 1. Seed yield (kg/ha) of the rapeseed and mustard varieties grown over three years

\begin{tabular}{|c|c|c|c|c|c|c|c|c|c|}
\hline \multirow{3}{*}{ Variety name } & \multirow{2}{*}{\multicolumn{4}{|c|}{$\begin{array}{l}\text { BAU component } \\
\text { Seed yield (kg/ha) }\end{array}$}} & \multirow{2}{*}{\multicolumn{4}{|c|}{$\begin{array}{c}\text { BCSKS component } \\
\text { Seed yield (kg/ha) }\end{array}$}} & \multirow{3}{*}{$\begin{array}{l}\text { Grand } \\
\text { Mean }\end{array}$} \\
\hline & & & & & & & & & \\
\hline & $1^{\text {st }} \mathrm{yr}$ & $2^{\text {nd }} y r$ & $3^{r d} y r$ & Mean & $1^{\text {st }} \mathrm{yr}$ & $2^{\text {nd }} \mathrm{yr}$ & $3^{r d} y r$ & Mean & \\
\hline BARI sarisha-14 & - & 1892.0 & 1747.1 & 1819.5 & - & 1883.3 & 1765.7 & 1824.5 & 1822.0 \\
\hline BARI sarisha-15 & 1112.7 & 1863.0 & 1717.5 & 1564.4 & 1146.7 & 1875.0 & 1725.2 & 1582.3 & 1573.4 \\
\hline BINA sarisha-4 & - & 1609.3 & 1678.1 & 1643.7 & - & 1608.7 & 1708.3 & 1658.5 & 1651.1 \\
\hline BINA sarisha-7 & - & - & - & - & - & 1410.0 & - & 1410.0 & 1410.0 \\
\hline Unnata Tori-7 & 893.0 & 1282.5 & 1402.9 & 1192.8 & - & 1281.6 & 1398.6 & 1340.1 & 1266.5 \\
\hline Mean & & & & 1555.1 & & & & 1563.1 & 1544.6 \\
\hline
\end{tabular}

Cost of production of rapeseed and mustard varieties beginning from land preparation up to seed processing were estimated and the results over three years have been shown in the Table 2. Cost of production varied from farmer to farmer or variety to variety due to number of plough given for land preparation, sowing method i.e. broadcasting or line sowing, weeding operation done or not, irrigation given or not etc. Thus, considering the components BAU and BCSKS separately, it was Tk. 26856 and 27976 Tk. Per hectare, respectively and the average cost was Tk. 27770.Considerly variety wise cost, the highest was Tk. 30394 for the variety BINA sorisha-7 and the lowest was Tk. 26185 for the variety Unnata tori -7. Cost of production for the other varieties was Tk. 28095, 26726 and 27451 for the varieties BARI sarisha-14, 15 and BINA sarisha-4, respectively.

Table 2. Cost of Production of the rapeseed and mustard varieties (tk/ha) grown over three years

\begin{tabular}{|c|c|c|c|c|c|c|c|c|c|}
\hline \multirow{3}{*}{ Variety name } & \multicolumn{4}{|c|}{ BAU component } & \multicolumn{4}{|c|}{ BCSKS component } & \multirow{3}{*}{$\begin{array}{l}\text { Grand } \\
\text { Mean }\end{array}$} \\
\hline & \multicolumn{4}{|c|}{ Cost of Production (tk/ha) } & \multicolumn{4}{|c|}{ Cost of Production (tk/ha) } & \\
\hline & $1^{\text {st }} \mathrm{yr}$ & $2^{\text {nd }} y r$ & $3^{r d} y r$ & Mean & $1^{\text {st }} \mathrm{yr}$ & $2^{\text {nd }} y r$ & $3^{\mathrm{rd}} \mathrm{yr}$ & Mean & \\
\hline BARI sarisha-14 & - & 28075 & 28986 & 28530 & - & 29061 & 26261 & 27661 & 28095 \\
\hline BARI sarisha-15 & 24555 & 24798 & 29874 & 26409 & 25762 & 29180 & 26183 & 27041 & 26725 \\
\hline BINA sarisha-4 & - & 25297 & 29077 & 27187 & - & 29244 & 26188 & 27716 & 27451 \\
\hline BINA sarisha-7 & - & - & - & - & - & 30394 & - & 30394 & 30394 \\
\hline Unnata Tori-7 & 23443 & 23716 & 28738 & 25299 & - & 28364 & 25780 & 27072 & 26185 \\
\hline Mean & & & & 26856 & & & & 27976 & 27770 \\
\hline
\end{tabular}

Gross income and gross return obtained from rapeseed and mustard cultivation over three years have been shown in the Tables 3 and 4, respectively. Both gross income and gross return varied from variety to variety depending on seed yield and market price of the seeds. Thus, the highest gross income and gross return of tk. 95519 and 6745.6 were recorded for the variety BARI Sarisha-14. These figures for the varieties BARI Sarisha-15 and BINA Sarisha-4 are more or less similar. While gross income and gross return gained from the variety Unnata Tori-7 were tk. 57553 and 31447, respectively. Considering both the components and all the five varieties the ultimate gross income and gross return from rapeseed and mustard cultivation were tk. 78180 and tk. 50471, respectively.

Table 3. Gross income generated (tk/ha) from the rapeseed and mustard varieties grown over three years

\begin{tabular}{|c|c|c|c|c|c|c|c|c|c|}
\hline \multirow{3}{*}{ Variety name } & \multicolumn{4}{|c|}{ BAU component } & \multicolumn{4}{|c|}{ BCSKS component } & \multirow{3}{*}{$\begin{array}{l}\text { Grand } \\
\text { Mean }\end{array}$} \\
\hline & \multicolumn{4}{|c|}{ Gross income (tk/ha) } & \multicolumn{4}{|c|}{ Gross income (tk/ha) } & \\
\hline & $1^{\text {st }} \mathrm{yr}$ & $2^{\text {nd }} y r$ & $3^{r d} y r$ & Mean & $1^{\text {st }} \mathrm{yr}$ & $2^{\text {nd }} y r$ & $3^{r d} y r$ & Mean & \\
\hline BARI sarisha-14 & - & 104598 & 87357 & 95977 & - & 101839 & 88285 & 95062 & 95519 \\
\hline BARI sarisha-15 & 62939 & 101162 & 85646 & 83249 & 64509 & 101103 & 86257 & 83956 & 83602 \\
\hline BINA sarisha-4 & - & 82594 & 83805 & 83199 & - & 81455 & 85416 & 83435 & 83317 \\
\hline BINA sarisha-7 & - & - & - & - & - & 70910 & - & 70910 & 70910 \\
\hline Unnata Tori-7 & 48475 & 61972 & 57076 & 55841 & - & 62588 & 55942 & 59265 & 57553 \\
\hline Mean & & & & 79566 & & & & 78526 & 78180 \\
\hline
\end{tabular}


Table 4. Gross return gained (tk/ha) from the rapeseed and mustard varieties grown over three years

\begin{tabular}{|c|c|c|c|c|c|c|c|c|c|}
\hline \multirow{3}{*}{ Variety name } & \multirow{2}{*}{\multicolumn{4}{|c|}{$\begin{array}{l}\text { BAU component } \\
\text { Gross return (tk/ha) }\end{array}$}} & \multirow{2}{*}{\multicolumn{4}{|c|}{$\begin{array}{l}\text { BCSKS component } \\
\text { Gross return (tk/ha) }\end{array}$}} & \multirow{3}{*}{$\begin{array}{l}\text { Grand } \\
\text { Mean }\end{array}$} \\
\hline & & & & & & & & & \\
\hline & $1^{\text {st }} y r$ & $2^{\text {nd }} y r$ & $3^{r d} \mathrm{yr}$ & Mean & $1^{\text {st }} \mathrm{yr}$ & $2^{\text {nd }} y r$ & $3^{r d} y r$ & Mean & \\
\hline BARI sarisha-14 & - & 76612 & 58370 & 67491 & - & 72822 & 62023 & 67422 & 67456 \\
\hline BARI sarisha-15 & 38383 & 76445 & 55771 & 56866 & 38746 & 71981 & 60073 & 56933 & 56899 \\
\hline BINA sarisha-4 & - & 57575 & 54728 & 56151 & - & 52268 & 59228 & 55748 & 55949 \\
\hline BINA sarisha-7 & - & - & - & - & - & 40608 & - & 40608 & 40608 \\
\hline Unnata Tori-7 & 25032 & 38494 & 28338 & 30621 & - & 34384 & 30162 & 32273 & 31447 \\
\hline Mean & & & & 52782 & & & & 50596 & 50471 \\
\hline
\end{tabular}

During three years studyperiod, the varieties BRRI dhan 28, 29 \& BINA dhan 8 were mostly grown as Boro. The average per hectare production was 5.05 ton and gross income obtained from it was tk. 71,138 . Average per hectare cost of production was tk. 40,203. Thus, gross return obtained from Boro rice was tk. 30,935 per hectare. Therefore, it was estimated that a total of tk. 53,172 as gross return obtained from Aman \& Boro cultivation. But with the addition of rapeseed and mustard with it i.e. Aman+ rapeseed and mustard +Boro the farmers' gross income was tk. 1, 03,643. So, an additional income of tk. 50471 per hectare was achieved by the farmers for growing three crops instead of two and cropping intensity of the involved farmers became $300 \%$.

All the farmers under the present study expressed their satisfaction in all respects. They are willing to grow rapeseed and mustard in between Aman and Boro in future. A good number of farmers are also willing to produce quality rapeseed and mustard seeds for their own and their areas.

\section{Conclusion and Recommendation}

At times rapeseed and mustard was considered as a major crop but now-a-days it is considered as a minor one. As a result less attention has been given for its improvement. Once developed varieties of this crop was released through a long and appropriate procedure of the NSB. But now -a-days it is registered through a short-cut process. Once BADC paid much attention for its seed multiplication and DAE for its demonstration, dissemination etc. But now this activity has been slowed down. So, the country is not getting suitable varieties as required and the farmers are not much aware about the newly developed varieties and they are not getting quality seeds adequately. On the other hand, the land used during the rabi season are covered by so many crops in addition of rapeseed and mustard. So rapeseed and mustard as a crop has to complete intensively with many other crops and its return was found to be a bit less from some other rabi crops. So, the farmer has no other way to leave the crop slowly. In such a situation the present study has been started functioning, that is incorporation of rapeseed and mustard between Aman and Boro rice. If a considerable area of land remains fallow between Aman and Boro can be taken into rapeseed and mustard cultivation, then the country will be benefited enormously in various ways. The research findings indicated that Aman-rapeseed and mustard-Boro cropping pattern is applicable in some areas of Bangladesh. This will increase oilseed production of the country as well as total income of the farmers.

To establish the cropping pattern Aman-rapeseed and mustard-Boro throughout the country intensively programme should be taken involving research organizations like BAU, BARI, BINA etc.; seed multiplication organization like BADC, demonstration and seed distribution organization like DAE and some NGOs of the country.

\section{Acknowledgement}

This project was funded by Krishi Gobeshona Foundation (KGF) Entitle "Intensification of rice based cropping system incorporating short duration oilseed mustered varieties" Project ID No-(CN/FRP): C-4.1, Period: June 2011 to May 2014. 


\section{References}

Dixon, J.A., Gibbon, D.P. and Gulliver, A. 2001. Farming Systems and Poverty: Improving Farmers' Livelihoods in a Changing World. Rome and Washington, DC: Food and Agriculture Organization (FAO) and Word Bank.

Altieri, M.A. 1995. Agroecology: The Science of Sustainable Agriculture. Boulder, CO: Westview Press.

Gliessman, S.R. 2007. Agroecology: The Ecology of Sustainable Food Systems. Boca Raton, FL: CRC Press.

Uphoff, N. ed. 2002. Agroecological Innovations: Increasing Food Production with Participatory Development. London: Earthscan.

Dash T.K. and Pal, A. 2011. Growing Crops with SRI Principles. Bhubaneswar: SRI Secretariat and Sir Dorabji Tata Trust.

Araya, H., Edwards, S., Asmelash, A., Legasse, H., Zibelo, G.H., Mohammed, E. and Misgina, S. 2013. SCl: Planting with Space. Farming Matters. 29:35-37.

Watershed Organisation Trust. 2013. SCl: System of Crop Intensification - A Step towards Climate-Resistant Agriculture. Pune: WOTR. 